\title{
VARIASI GENETIK IKAN TUNA SIRIP KUNING, Thunnus albacares DENGAN ANALISIS ELEKTROFORESIS ALLOZYME DAN Mt-DNA
}

\author{
Gusti Ngurah Permana"), Jhon Harianto Hutapea"), Haryanti"), dan Sari Budi Moria Sembiring*)
}

\begin{abstract}
ABSTRAK
Sampel ikan tuna sirip kuning, T. albacares diambil dari tiga lokasi (perairan Bali, Sulawesi Utara, dan Maluku Utara) dan dilakukan analisis variasi genetik dengan metode elektroforesis allozyme menggunakan 15 enzim dan mt-DNA dengan 4 enzim restriksi. Hasil penelitian ini diperoleh 4 lokus enzim polimorfik yaitu: Idh-*2 (isocitrate dehydrogenase), Gpi-2* (glucose phoshate dehydrogenase), Mdh-1* (malate dehydrogenase), dan Est-1* (esterase). Frekuensi alel allozyme terlihat adanya perbedaan yang nyata $(\mathrm{Fst}=0,12 ; \mathrm{P}<0,05)$ antar lokasi yaitu Bali $(A, B, C, D)$, Sulawesi Utara dan Maluku Utara (A, B, C). 15 komposit haplotipe ditemukan pada populasi Bali, Sulawesi Utara, dan Maluku Utara. Haplotype diversity pada populasi Bali 0,886; Sulawesi Utara 0,790; dan Maluku Utara 0,785; dengan rata-rata dari haplotype diversity adalah 0,857. Jarak genetik dari ketiga populasi berkisar antara 0,003--0,023 (rata-rata 0,016). Populasi Maluku Utara dan Sulawesi Utara mempunyai jarak genetik terdekat yaitu 0,003. Hal ini merupakan indikator bahwa Sulawesi Utara dan Maluku Utara sering digunakan sebagai jalur migrasi dengan adanya kesamaan alel yang ditemukan pada kedua populasi tesebut, jika dibandingkan dengan populasi Bali $(0,023)$.
\end{abstract}

ABSTRACT: Genetic variation of yellow fin tuna, Thunnus albacares inferred by allozyme electrophoresis and mt-DNA analysis. By: Gusti Ngurah Permana, Jhon Harianto Hutapea, Haryanti, and Sari Budi Moria Sembiring

Samples of yellow fin tuna T. albacares were taken from three locations i.e. Bali, North Sulawesi, North Maluku, and analyzed by allozyme electrophoresis using 15 enzymes and mt-DNA amplification using PCR and then digested by 4 restriction enzymes. Result of this research is found that 4 loci polymorphism in allozyme i.e. GPI, EST, IDH, and MDH. Frequency of allel allozymes shown significantly differences $(F s t=0.12, P<0.05)$ at total data locus from each location of Bali $(A, B, C, D)$, North Sulawesi and North Maluku (A, B, C). 15 composite haplotype of mt-DNA refound from Bali, North Sulawesi, and North Maluku populations. Haplotype diversity of Bali (0.886), North Sulawesi (0.790), and North Maluku (0.785), with average: 0.857. Genetic distances of third populations were ranged from 0.003--0.023 (average: 0.016). North Maluku and North Sulawesi populations have closest genetic distance (0.003), this is indicated that North Sulawesi and North Maluku populations is often used as strip of migration which an existence equally of allel at both of populations than compared with Bali population (0.023).

KEYWORDS: allozyme, mt-DNA, genetic, yellowfin tuna

\footnotetext{
*) Peneliti pada Balai Besar Riset Perikanan Budidaya Laut, Gondol
} 


\section{PENDAHULUAN}

Ikan tuna sirip kuning (yellowfin tuna), Thunnus albacares merupakan salah satu spesies ikan yang mempunyai nilai ekonomis penting dalam perikanan di dunia (Gambar 1). Mulai tahun 2002 upaya domestikasi dan perbenihan ikan tuna sirip kuning dalam bak terkontrol telah dilakukan di Balai Besar Riset Perikanan Budidaya Laut, Gondol-Bali. Pengembangan program domestikasi dapat mengurangi tekanan pada populasi alam dan untuk mengembangkan industri perbenihan dengan tetap melakukan monitoring terhadap variasi genetiknya (Hedgecock et al., 1976; Lester, 1983; Taniguchi et al., 1994).

Genetika populasi ikan tuna dengan cakupan geografis dari seluruh laut Indonesia mempunyai struktur yang berbeda-beda sebagai akibat adanya keterbatasan laju migrasi gen. Bukti pembedaan stok yang kecil ditemukan di dalam dua jenis ikan hiu (Lavery \& Shaklee, 1989), empat spesies cumi-cumi (Yeatman \& Benzie, 1994), perbedaan struktur populasi ini juga ditemukan pada tiram mutiara (pearl oyster) (Johnson \& Joll, 1993). Variasi genetik suatu populasi merupakan sumber daya biologi yang penting untuk diketahui serta mempunyai manfaat untuk penentuan strategi pembenihan terutama dalam menentukan calon induk yang mempunyai kualitas genetik tinggi. Deteksi variasi genetik secara elektroforesis (Sugama \& Priyono, 1998), dan mt-DNA dapat digunakan sebagai marker genetik. Metode ini telah banyak digunakan untuk mengetahui variasi genetik dan telah dicobakan pada beberapa jenis ikan antara lain ikan bandeng dan Red Sea Bream (Sugama, et al., 1988), Cheilinus undulatus (Wibowo, 2001), Penaeus monodon (Sugama et al., 1996; Imron et al., 1999) dan Lutjanus malabaricus (Elliott, 1996). Tujuan dari penelitian adalah untuk mengetahui variasi genetik ikan tuna dari tiga populasi dengan menggunakan metode allozyme dan mt-DNA sebagai data dasar untuk melakukan program breeding yang terarah.

\section{MATERI DAN METODE}

Sampel diambil dari tiga lokasi perairan (Gambar 2) yaitu: Bali (perairan Bali Utara), Sulawesi Utara (Kalesey), dan Maluku Utara (Ternate, Kodya). Sampel yang dipergunakan untuk analisis allozyme adalah: otot daging, liver, jantung, dan mata sedangkan untuk analisis mt-DNA ekstraksi dari jaringan otot daging.

Sampel ikan tuna dari Bali, Sulawesi Utara, dan Maluku Utara memiliki kisaran panjang cagak rata-rata setiap populasi adalah $78,72 \pm$ $12,89 \mathrm{~cm} ; 78,99 \pm 12,89 ;$ dan $72,54 \pm 38,89$ $\mathrm{cm}$ serta bobot rata-rata 10,7 $\pm 6,92 ; 10,5 \pm$ 4,39; dan 12,28 $\pm 6,45 \mathrm{~kg}$ (Tabel 1).

\section{Analisis Allozyme}

\section{- Preparasi jaringan}

Sampel diambil dan dibawa ke laboratorium dalam keadaan segar. Jaringan disayat dan dimasukkan dalam plate sampel. Jaringan mata, otot daging, jantung, dan hati diekstraksi dengan $\mathrm{MgCl}_{2} 1 \mathrm{M}$., Tris $0,5 \mathrm{M}$. Preservasi sampel untuk analisis elektroforesis allozyme dalam freezer bersuhu $-20^{\circ} \mathrm{C}$.

\section{- Gel dan buffer}

Bufer elektroforesis menggunakan Citric Acid Aminopolymorpholine $\mathrm{pH} 6$ yang dibuat dengan mencampur citric acid $15 \mathrm{~g}$ dan

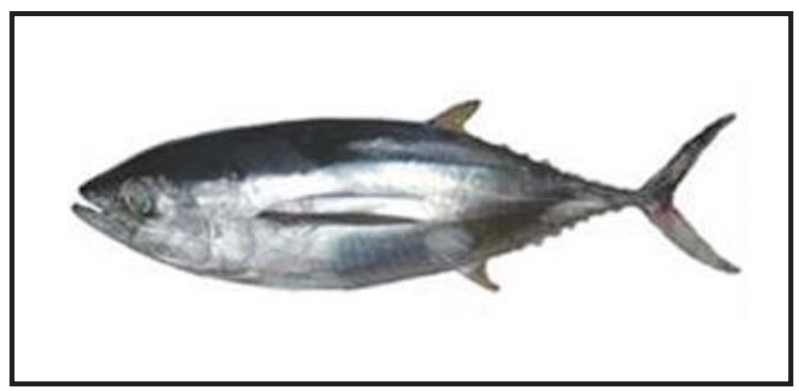

Gambar 1. Ikan tuna sirip kuning, Thunnus albacares yang ditangkap di perairan Bali Utara

Figure 1. Yellowfin tuna, Thunnus albacares captured in North Bali sea 


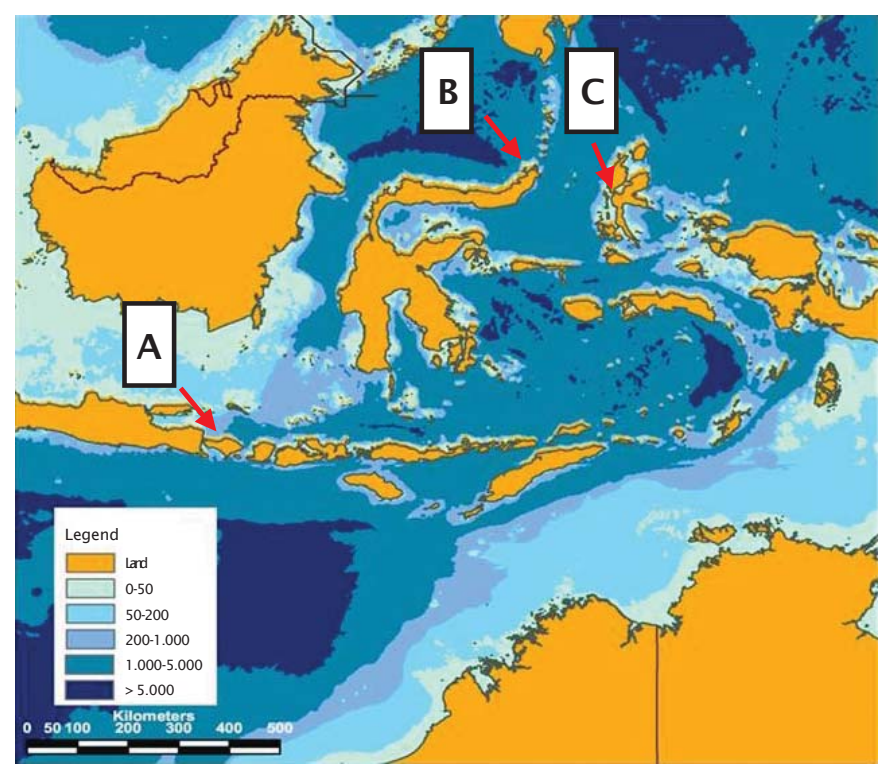

Gambar 2. Peta lokasi pengambilan sampel ikan tuna sirip kuning (A. Bali, B. Sulawesi Utara, C. Maluku Utara)

Figure 2. Map showing sampling location of yellowfin tuna (A. Bali, B. North Sulawesi, C. North Maluku)

Tabel 1. Deskripsi panjang dan bobot sampel ikan tuna dari tiga lokasi (Bali, Sulawesi Utara, Maluku Utara)

Table 1. Description of length and weight of yellow fin tuna from three locations (Bali, North Sulawesi, North Maluku)

\begin{tabular}{llcccc}
\hline $\begin{array}{c}\text { Tanggal } \\
\text { Date }\end{array}$ & $\begin{array}{c}\text { Lokasi } \\
\text { Locations }\end{array}$ & $\begin{array}{c}\text { Jumlah sampel } \\
\text { No. of samples }\end{array}$ & $\begin{array}{c}\text { Spesies } \\
\text { Species }\end{array}$ & $\begin{array}{c}\text { Panjang cagak } \\
\text { Fork length } \\
(\mathbf{c m}) \pm \mathbf{s d}\end{array}$ & $\begin{array}{c}\text { Bobot } \\
\text { Weight } \\
(\mathbf{k g}) \pm \mathbf{s d}\end{array}$ \\
\hline $2 / 2 / 2004$ & Bali & 32 & T. albacares & $78.72 \pm 12.89$ & $10.70 \pm 6.92$ \\
$18 / 3 / 2004$ & (Bali Utara) & 40 & & $79.40 \pm 20.64$ & $14.7 \pm 8.92$ \\
$2 / 2 / 2005$ & 50 & & $84.44 \pm 16.90$ & $13.82 \pm 11.56$ \\
\hline $5 / 4 / 2004$ & Sulawesi Utara & 63 & T. albacares & $78.99 \pm 12.89$ & $10.50 \pm 4.39$ \\
$1 / 10 / 2005$ (Kalesey) & 50 & & $73.71 \pm 9.03$ & $10.30 \pm 4.39$ \\
\hline $11 / 9 / 2004$ Maluku Utara & 46 & T. albacares & $72.54 \pm 38.89$ & $12.28 \pm 6.45$ \\
$11 / 9 / 2005$ & (Ternate, Kodya) & 50 & & $70.81 \pm 4.47$ & $9.82 \pm 6.92$ \\
\hline
\end{tabular}

aminoprophylmorpholine $24 \mathrm{~mL}$ selanjutnya ditambahkan akuades dengan total volume $1.000 \mathrm{~mL}$. Hydrolyzed starch potatoes gel (12\% $\mathrm{v} / \mathrm{w}$ ) dibuat dari 48 gram potato starch yang dilarutkan dengan $2 \mathrm{~mL} \mathrm{MgCL}, 1 \mathrm{M} 10 \mathrm{~mL} \mathrm{KCN}$; $0,1 \mathrm{~N} ; 8 \mathrm{~mL}$ bufer CAAPM-6 dán aquades dengan total volume $400 \mathrm{~mL}$.

\section{- Running elektroforesis}

Potongan kertas blotting yang sudah menyerap enzim pada jaringan ditempelkan berurutan di antara belahan gel. Pada kedua ujung dan tengah ditempelkan marker (fast blue). Proses elektroforesis dilakukan pada 
refrigerator $\left(4^{\circ} \mathrm{C}\right)$ dengan arus konstan $80 \mathrm{~mA} /$ $\mathrm{cm}^{2}$, dengan voltase 110 volt, selama 240 menit (4 jam).

\section{- Pewarnaan}

Metode analisis mengikuti prosedur yang dikembangkan oleh Sugama \& Prijono (1998). Enzim yang dianalisis sebanyak 15 enzim sebagai berikut: alcohol dehydrogenase (ADH), malatedehydrogenase (MDH), lactate dehydrogenase (LDH), sorbitol dehydrogenase (SDH), superoxide dehydrogenase (SOD), isocitrate dehydrogenase (IDH), Malic enzyme (ME), $\mu$ glycerolphoshate dehydrogenase $(\mu \mathrm{GPD})$, posphoglucomutase (PGM), glucose phosphate isomerase (GPI), 6-posphoguconate dehydrogenase (6-PGD), mannose phosphate dehydrogenase (MPI), esterase (EST), aspartate aminotransferase (AAT), sarcoplasmic protein (SP).

\section{Mitokondria DNA}

\section{- Ikan uji}

Ikan uji yang digunakan untuk analisis mtDNA adalah ikan tuna sirip kuning yang telah dikoleksi dari tiga lokasi yang diambil secara acak masing masing berjumlah 25 sampel untuk analisis DNA dari jumlah total 331 ekor ikan sampel untuk analisis allozyme.

\section{- Ekstraksi genome mt-DNA}

Ekstraksi genome mt-DNA dilakukan mengikuti modifikasi metode Ovenden (2000). Jaringan otot daging dihancurkan dalam 500 $\mathrm{mL}$ larutan $10 \%$ Chelex-100 yang dimasukkan dalam eppendorf tube dan ditambahkan $5 \mathrm{~mL}$ proteinase kinase $(20 \mathrm{mg} / \mathrm{mL})$ dan dipanaskan $55^{\circ} \mathrm{C}$ dalam waterbath selama 3--4 jam. Selanjutnya larutan ini dipanaskan lagi pada suhu $89^{\circ} \mathrm{C}$ selama 8 menit, dan didinginkan pada suhu kamar hingga dingin sebelum di tambahkan $55 \mathrm{~mL}$ TE buffer (10 mM Tris $\mathrm{pH}-8$; 1 mM EDTA). Genome mt-DNA dapat diperoleh dengan cara sentrifugasi selama 5 menit dengan kecepatan 13.000 rpm. Larutan pada lapisan atas dan berwarna jernih merupakan genom DNA dan di pindahkan ke dalam eppendorf tube baru dan disimpan pada suhu $-20^{\circ} \mathrm{C}$ untuk analisis lebih lanjut.

\section{- Amplifikasi PCR genome mt-DNA}

Genome DNA diamplifikasi menggunakan pasangan primer forward CB3R-LT (5'CACATTAAACCTGAATGATATTT-3') dan reverse 12SAR-H (3'-ATAGTG GGGTATCTAATCCC AGTT-5') untuk memperoleh hasil DNA dengan fragmen tunggal (Palumbi \& Baker, 1994).

Amplifikasi dilakukan menggunakan beberapa larutan pereaksi dengan total volume $25 \%$ L yang terdiri atas: double distillited $\mathrm{H}_{2} \mathrm{O}: 14,75 \mu \mathrm{L} ; 2,5 \mathrm{mM}$ dNTP: $2,5 \mu \mathrm{L} ; 10 \times$ PCR bufer 2,5 $\mu \mathrm{L}$; primer 1 (forward) CB3RL-T: 1,25 $\mu \mathrm{L}$; primer 2 (reverse) 12SAR-H: 1,25 $\mu \mathrm{L}$, taq DNA polymerase: $0,25 \mu \mathrm{L}$; template DNA: 2,5 $\mu \mathrm{L}$. Thermal cycler untuk amplifikasi DNA terlihat pada Tabel 2.

Sebagai molekuler marker digunakan DNA ladder $1 \mathrm{~kb}$ dan $100 \mathrm{bp}$. Elektroforesis dengan agarose gel $1 \%$ dan TBE $0,5 x$ bufer sebagai running buffer pada 100 volt selama 30 menit. Hasil amplifikasi template DNA selanjutnya dipotong secara terpisah dengan menggunakan 4 enzim restriksi yaitu Mnl I, Msp I, Nla III, dan Taq I (Niwa et al., 2003) Setelah 3--4 jam inkubasi pada suhu $37^{\circ} \mathrm{C}$ kecuali Taq I suhu

Tabel 2. Program thermal cycler amplifikasi PCR DNA mt-DNA ikan tuna sirip kuning Table 2. Thermal cycler program for PCR amplification of $m t-D N A$ yellowfin tuna

\begin{tabular}{lccc}
\hline \multicolumn{1}{c}{$\begin{array}{c}\text { Reaksi } \\
\text { Reaction }\end{array}$} & $\begin{array}{c}\text { Siklus } \\
\text { Cycle }\end{array}$ & $\begin{array}{c}\text { Suhu } \\
\text { Temperature }\end{array}$ & $\begin{array}{c}\text { Lama reaksi } \\
\text { Duration }\end{array}$ \\
\hline Initial denaturation & 1 & $95^{\circ} \mathrm{C}$ & 3 menit (minutes) \\
\hline Denaturation & 30 & $95^{\circ} \mathrm{C}$ & 1 menit (minutes) \\
Annealing & $50^{\circ} \mathrm{C}$ & 1 menit (minutes) \\
Extention & & $72^{\circ} \mathrm{C}$ & 2 menit (minutes) \\
\hline Final extention & 1 & $72^{\circ} \mathrm{C}$ & 10 menit (minutes) \\
\hline Preservation & & $4^{\circ} \mathrm{C}$ & \\
\hline
\end{tabular}


inkubasi adalah $65^{\circ} \mathrm{C}$. Sampel dicampur dengan loading buffer dan dielektroforesis pada $1,5 \%$ gel agarose dalam $0,5 \times$ TBE buffer selama 40 menit. Pewarnaan dengan ethidium bromide $(5 \mathrm{mg} / \mathrm{mL}$ ) selama 15 menit, fragmen divisualisasi dengan UV transilluminator pada panjang gelombang $320 \mathrm{~nm}$.

\section{Analisis Data}

Uji Chi-square digunakan untuk menentukan keabsahan genotip yang teramati yang diduga dengan hukum kesetimbangan HardyWeinberg, dengan derajat bebas $(\mathrm{df})=(\mathrm{n} 2-\mathrm{n}) /$ 2 di mana n: jumlah alel per lokus (Sokal \& Rohlf, 1981). Heterosigositas teramati (Ho) diketahui dengan menghitung genotip yang teramati, dengan menjumlah individu yang heterosigot dengan jumlah individu yang dianalisis. Untuk mengetahui variasi DNA antar populasi, susunan haplotipe untuk masing-masing enzim restriksi dikumpulkan sebagai komposit haplotipe menggunakan analisis molekular TFPGA (tools for population genetic analysis) version 1.3 (Miller, 1997).

\section{HASIL DAN BAHASAN}

\section{Spesifik Jaringan dan Buffer}

Tabel 3 merupakan hasil analisis spesifik jaringan dan buffer yang baik dipergunakan untuk analisis allozyme pada ikan tuna sirip kuning, T. albacares. Dari Tabel 3 terlihat bahwa, ekspresi gen sebagian besar terlihat jelas pada jaringan otot daging dan hati serta buffer CAAPM- 6 merupakan bufferyang sesuai untuk elektroforesis allozyme.

\section{Variasi genetik}

Hasil analisis elektroforesis pada 15 enzim terdeteksi 23 lokus dan 4 lokus di antaranya polimorfik yaitu Idh-*2 (isocitrate dehydrogenase), Gpi-2* (glucose phoshate dehydrogenase), Mdh-1 * (malate dehydrogenase) dan Est1 * (esterase).

Lokus Gpi-2* dan Idh*2 dikontrol oleh tiga alel yaitu (A,B, dan $C)$. GPI (glucose phosphate isomerase merupakan golongan enzim yang mengontrol pertumbuhan. Menurut Haris et al., (1976) lokus Gpi diperlukan dalam reaksi metabolisme karbohidrat terutama pada jalan pentosa fosfat (heksosa monofosfat shunt). Lokus esterase dan malate dehydrogenase masing-masing dikontrol oleh dua alel. Variasi genetik dari tiga populasi ikan tuna sirip kuning terlihat pada Tabel 4.
Nilai heterosigositas dari masing-masing populasi berkisar antara 0,008--0,022 (rata-rata 0,017 ). Persentase lokus polimorfik berkisar antara 0,086--0,130 (rata-rata 0,115 ) dan jumlah alel perlokus antara 1,173--1,391 (rata-rata 1,260) (Tabel 4). Dari hasil tersebut terlihat variasi genetik tertinggi adalah populasi Bali dan Maluku Utara $(0,022)$, akan tetapi jumlah alel perlokus populasi Bali $(1,391)$ lebih tinggi dari populasi Maluku Utara yaitu 1,137. Populasi dengan variasi genetik paling rendah adalah populasi Sulawesi Utara $(0,008)$. Populasi dengan variasi genetik yang tinggi akan memiliki peluang hidup yang semakin tinggi untuk beradaptasi dengan perubahan lingkungan. Heterosigositas yang tinggi memungkinkan perbaikan mutu genetik populasi dengan mengeksploitasi gen-gen yang menguntungkan. Genotip heterosigositas resesif mengakibatkan detrimental yaitu kekurangan enzim penting yang diproduksi oleh alel dominan yang berhubungan dengan penurunan fekunditas, penurunan daya hidup atau peningkatan mortalitas, penurunan daya tahan terhadap penyakit dan laju pertumbuhan. Variasi genetik suatu mahluk hidup dapat muncul karena mutasi, seleksi alam, pengaruh lingkungan, dan perkawinan. Apabila faktor di atas muncul dapat menyebabkan terjadinya perubahan suatu genetik individu dan selanjutnya terjadi perubahan susunan genetik populasi yang terbentuk dari individu tersebut. Perbedaan nilai heterosigositas menggambarkan adanya perbedaan lingkungan di antara populasi. Pada lingkungan yang stabil akan lebih sedikit ditemukan variasi alel daripada kondisi lingkungan yang labil, karena laju mutasi atau seleksi lingkungan relatif rendah (Sugama et al., 1996).

\section{Mitokondria DNA}

Amplifikasi genome mt-DNA menghasilkan fragmen tunggal dengan panjang fragment 1.800 bp, seperti pada Gambar 3.

Lokus gen tunggal digunakan untuk mengasumsikan banyaknya alel pada masingmasing profil enzim restriksi menunjukkan bahwa fragmen yang tidak mempunyai site restriksi dinyatakan $\mathrm{A}$ alel, sedangkan yang mempunyai satu site dinyatakan B alel dan seterusnya seperti dinyatakan oleh Chow (1998) dan terlihat pada Gambar 4.

Pola pemotongan dari fragmen mt-DNA dengan menggunakan enzim Msp I mempunyai 2 alel yaitu alel $A$ dan $B$, enzim Taq I terdapat 3 alel yaitu A, B, dan C, Nla III 2 alel yaitu A dan 
Tabel 3. Jaringan spesifik dan bufer yang digunakan dalam analisis elektroforesis allozyme Table 3. Tissue specific and buffer systems tested for allozyme electrophoresis

\begin{tabular}{|c|c|c|c|}
\hline Enzim (Enzymes) & $\begin{array}{l}\text { Lokus } \\
\text { Locus }\end{array}$ & $\begin{array}{l}\text { Bufer } \\
\text { Buffer }\end{array}$ & $\begin{array}{l}\text { Jaringan } \\
T \text { issue }\end{array}$ \\
\hline Alcohol dehydrogenase (1111) & $A d h^{*}$ & CAAPM -6 & hati (liver ) \\
\hline a-Glycerolphosphate dehydrogenase (1118) & $a-G p d^{*}$ & CAAPM -6 & hati (liver ) \\
\hline \multirow[t]{2}{*}{ Lactate dehydrogenase (11127) } & Ldh-1* & CAAPM -6 & otot daging (muscle) \\
\hline & Ldh-2* & & \\
\hline \multirow[t]{3}{*}{ M alate dehydrogenase (11137) } & $M d h-1^{\star}$ & CAAPM -6 & otot daging (muscle) \\
\hline & M dh-2* & & \\
\hline & M dh-3* & & \\
\hline \multirow[t]{2}{*}{ Isocitrate dehydrogenase (11142) } & $\operatorname{ldh}-1^{\star}$ & CAAPM -6 & hati (liver ) \\
\hline & Idh-2* & & \\
\hline \multirow[t]{2}{*}{ P ho spho gluco mutase $\quad(2.7 .5 .1)$} & $P g m-1^{*}$ & CAAPM -6 & hati (liver ) \\
\hline & $\mathrm{Pgm}-2^{*}$ & & otot daging (muscle) \\
\hline 6-P ho spho gluconate dehydro genase (11144) & $6-\mathrm{Pgd} *$ & CAAPM -6 & hati (liver ) \\
\hline \multirow[t]{2}{*}{ Glucose phosphate isomerase } & Gpi-1* & CAAPM -6 & hati (liver ) \\
\hline & Gpi-2* & & otot daging (muscle) \\
\hline \multirow[t]{2}{*}{ M alic Enzyme (11140) } & $\mathrm{Me}-1^{\star}$ & CAAPM -6 & hati (liver) \\
\hline & $\mathrm{Me}$ - $1^{\star}$ & & \\
\hline Sarcoplasmic protein & $S p-1^{\star}$ & CAAPM -6 & otot daging (muscle) \\
\hline \multirow[t]{2}{*}{ Esterase (3.113) } & Est-1 $1^{\star}$ & CAAPM -6 & otot daging (muscle ) \\
\hline & Est-2* & & \\
\hline A spartate am ino transferase (2.6.11) & A at* & CAAPM -6 & hati (liver ) \\
\hline So rbitol dehydrogenase (11114) & $\mathrm{Sdh}^{\star}$ & CAAPM -6 & otot daging (muscle) \\
\hline Superoxide dismutase (115.11) & So d* & CAAPM -6 & otot daging (muscle) \\
\hline M annose phosphate dehydrogenase (5.3.18) & M pi* & CAAPM -6 & hati (liver ) \\
\hline
\end{tabular}

B sedangkan untuk Mnl I mempunyai 2 alel yaitu A dan B.

Dari empat enzim (Msp I, Taq, Nla III, dan $\mathrm{Mnl}$ I) mengasilkan 15 komposit haplotipe dari tiga populasi ikan tuna (Tabel 5). Level variasi genetik yang ditunjukkan dari haplotype diversity pada populasi Bali $(0,886)$, Sulawesi Utara $(0,790)$, dan Maluku Utara $(0,785)$. Hasil rata-rata dari haplotype diversity adalah 0,857. Nilai ini lebih tinggi jika dibandingkan dengan jenis ikan laut perenang cepat lainnya seperti ikan hiu $(0,64)$ (Heist, 1999). Tingginya variasi genetik pada ikan tuna dimungkinkan karena keadaan populasinya belum banyak terganggu khususnya populasi Bali dan Maluku Utara. Selain itu keadaan ini juga menunjukkan bahwa ikan tuna sirip kuning mempunyai migrasi yang cukup luas jika dibandingkan dengan jenis ikan laut lainnya, sehingga peluang breeding atau persilangan antar populasi (stock) lebih besar (Wild, 1994).

Haplotipe 5 (ADAC) merupakan haplotipe yang paling banyak ditemukan pada populasi Sulawesi Utara dan Maluku Utara, sedangkan haplotipe 1 (ADBB) paling banyak ditemukan pada populasi dari Bali sedangkan haplotipe 
Tabel 4. Variasi genetik populasi ikan tuna sirip kuning T. albacares dari alam, berdasarkan 23 lokus hasil analisis elektroforesis

Table 4. Summary of genetic variation of yellow fin tuna, T albacares population, based on electrophoretic analysis of 23 loci

\begin{tabular}{lccc}
\hline \multicolumn{1}{c}{ Paramet er (Item) } & Bali & $\begin{array}{c}\text { Sulawesi Utara } \\
\text { North Sulawesi }\end{array}$ & $\begin{array}{c}\text { Maluku Utara } \\
\text { North Maluku }\end{array}$ \\
\hline $\begin{array}{l}\text { Jumlah sample } \\
\begin{array}{l}\text { No of sample examined } \\
\text { Jumlah lokus }\end{array}\end{array}$ & 122 & 113 & 96 \\
$\begin{array}{l}\text { No of loci examined } \\
\text { Jumlah lokus polimorfik }\end{array}$ & 23 & 23 & 23 \\
$\begin{array}{l}\text { No of polymorphic loci } \\
\text { Persentase lokus polimorfik } \\
\% \text { of polymorphic loci }\end{array}$ & 0.130 & 0.086 & 3 \\
$\begin{array}{l}\text { Jumlah alel per lokus } \\
\text { No of allel per locus } \\
\text { Heterosigositas }\end{array}$ & 1.391 & 1.217 & 0.130 \\
\begin{tabular}{l} 
Heterozygosity : \\
\hline
\end{tabular} & 0.022 & 0.008 & 1.173 \\
\hline
\end{tabular}

10 (ABBB) ditemukan pada ketiga populasi. Beberapa haplotipe shared antara populasi dari Sulawesi Utara dan Maluku Utara tetapi tidak ada shared alel dengan populasi Bali. Keadaan ini menunjukkan bahwa populasi Sulawesi Utara dan Maluku Utara dapat ditempatkan pada satu gen pool.

Jarak genetik (genetic distance) (Rogers, 1972; Raymond \& Rousset, 1995) ketiga populasi: Maluku Utara, Sulawesi Utara, dan Bali terlihat pada dendrogram (Gambar 5).
Jarak genetik dari ketiga populasi berkisar antara 0,003--0,023 (rata-rata 0,016). Hal ini menunjukkan bahwa ikan tuna mempunyai migrasi yang cukup luas. Populasi Maluku Utara dan Sulawesi Utara mempunyai jarak genetik terdekat yaitu 0,003 . Hal ini mengindikasikan bahwa jarak genetik populasi berkorelasi erat dengan jarak geografis, selain itu pula dapat diasumsikan bahwa perairan Sulawesi Utara dan Maluku Utara sering digunakan sebagai jalur migrasi dengan adanya kesamaan allel pada kedua populasi tersebut, jika dibanding-

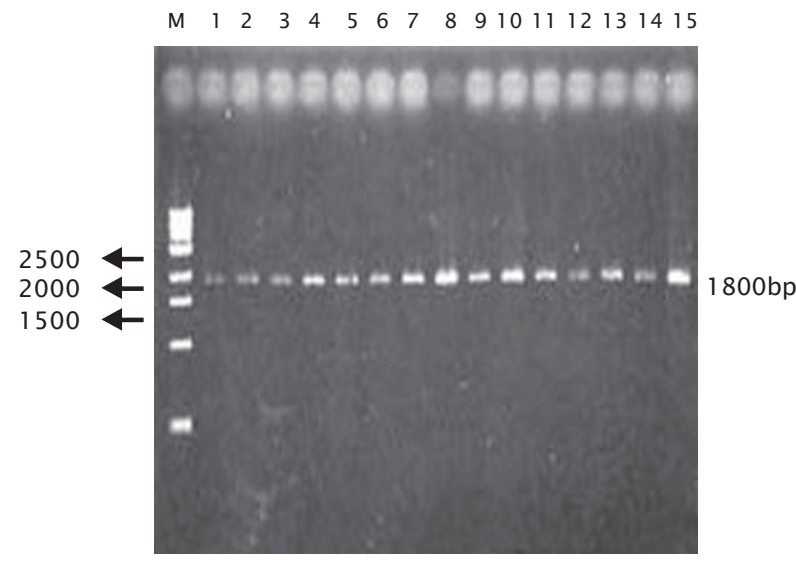

Gambar 3. Fragmen tunggal mt-DNA hasil amplifikasi PCR dari ikan tuna sirip kuning ( $T$. albacares)

Figure 3. Single band amplification of $m t-D N A$ from yellowfin tuna, T. albacares 

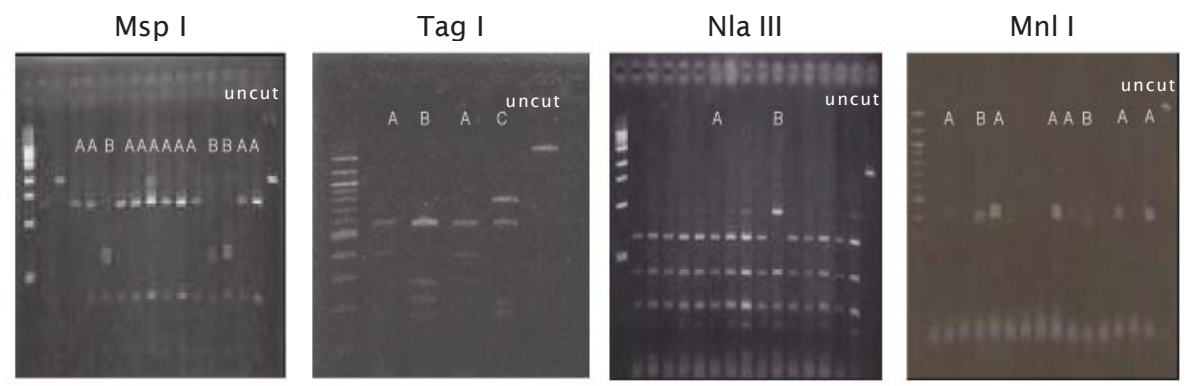

Gambar 4. Pola fragmen dari hasil pemotongan mt-DNA dengan menggunakan enzim restriksi Msp I, Tag I, Nla III, dan Mnl I

Figure 4. Pattern of $m t-D N A$ of T. albacares after digested by restriction enzymes Msp I, Tag I, NIa III, and MnI I

Tabel 5. Komposit haplotipe dari tiga populasi ikan tuna sirip kuning, Thunnus albacares

Table 5. Haplotype composites of three populations of yellowfin tuna, Thunnus albacares

\begin{tabular}{ccccc}
\hline No. & $\begin{array}{c}\text { Haplotipe } \\
\text { Haplotype }\end{array}$ & Bali & $\begin{array}{c}\text { Sulawesi Utara } \\
\text { North Sulawesi }\end{array}$ & $\begin{array}{c}\text { Maluku Utara } \\
\text { North Maluku }\end{array}$ \\
\hline 1 & A D B B & 8 & 0 & 0 \\
2 & A C B E & 4 & 0 & 0 \\
3 & A C A B & 0 & 2 & 1 \\
4 & B D A B & 2 & 0 & 0 \\
5 & A D A C & 0 & 16 & 12 \\
6 & D A B E & 1 & 0 & 0 \\
7 & A A B B & 0 & 1 & 5 \\
8 & A C B B & 0 & 1 & 0 \\
9 & A B B B & 5 & 0 & 2 \\
10 & A B B B & 2 & 2 & 0 \\
11 & B C B B & 0 & 0 & 1 \\
12 & B C A C & 2 & 0 & 2 \\
13 & A C A D & 0 & 0 & 3 \\
14 & A C A C & 0 & 3 & 0.865 \\
15 & A B A B & 1 & 0 & \\
\hline Diversitas haplotipe & 0.886 & 0.750 & \\
\hline Haplotype diversity & & &
\end{tabular}

kan dengan populasi Bali $(0,023)$. Ikan-ikan perenang cepat mempunyai jarak genetik yang lebih besar pada sub populasinya jika dibandingkan dengan habitat lainnya seperti ikan yang hidup di perairan karang berkisar antara 0,0001--0,002 (Sugama \& Prijono, 1998).

\section{KESIMPULAN}

Berdasarkan data dari elektroforesis allozyme, populasi ikan tuna sirip kuning ( $T$. albacares) yang berasal dari perairan Bali, Sulawesi Utara, dan Maluku Utara mempunyai 


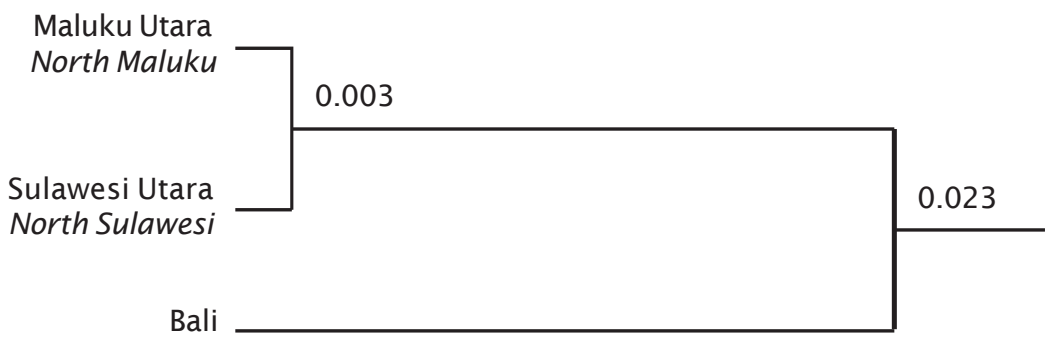

Gambar 5. Jarak genetik ikan tuna sirip kuning (T. albacares) dari 3 lokasi

Figure 5. Genetic distance of yellowfin tuna (T. albacares) from 3 locations

nilai heterosigositas 0,$022 ; 0.008$; dan 0,022 . Haplotype diversity dari mt-DNA adalah 0,886 ; 0,750; dan 0,865. Populasi Bali mempunyai nilai variasi genetik tertinggi dengan heterosigositas 0,022 dan Haplotype diversity dari mt-DNA adalah 0,886. Populasi Maluku Utara dan Sulawesi Utara mempunyai jarak genetik terdekat yaitu 0,003 selanjutnya adalah populasi Bali dengan jarak genetik 0,023. Metode elektroforesis allozyme dan mt-DNA yang dipergunakan untuk mengetahui variasi genetik ikan tuna dari berbagai lokasi memberikan hasil yang paralel.

\section{UCAPAN TERIMA KASIH}

Penulis mengucapkan terima kasih kepada Dr. Adi Hanafi sebagai Kepala Balai Besar Riset Perikanan Budidaya laut, Gondol-Bali, Bapak Akio Nakazawa expert tuna propagation project Overseas Fisheries Cooperation Foundation-Jepang dan seluruh staf teknisi Tuna dan bioteknologi BBRPBL-Gondol atas segala masukan dan bantuan selama penelitian ini dilakukan. Penelitian ini dibiayai dari anggaran APBN Tahun 2004 dan 2005.

\section{DAFTAR PUSTAKA}

Chow, S. 1998. Universal PCR primer for Calmodulin gene intron in fish. Fisheries Science. 64(6): 999-1,000.

Elliott, N.G. 1996. Allozyme and Mitochondrial DNA analysis of the tropical saddle-tail Sea pearch, Lutjanus malabaricus (Schneider), from Australian waters. Mar. Freshwater Res. 47: 869--876.

Haris, H. and D.A. Hopkinson. 1976. Handbook of enzyme electrophoresis in human genetics. Human Genetics. American Elsevier, New York. 428 pp.

Hedgecock, D., R.A. Shleser, and Nelson. 1976. Applications of biochemical genetics to aquaculture. J. Fish. Res., Board Can. 3(33): 11,108--11,109.

Heist, E.J. 1999. A review of population genetics in sharks. Am F. S. S. Symp. 23: 161-168.

Imron, K. Sugama, K. Sumantadinata, and K. Soewardi. 1999. Genetic variation in cultured stocks of tiger shrimp (Penaeus monodon) in Indonesia. Indonesian Fish. Res. J. 5(1): 10--18.

Johnson, M.S., and L.M. Joll. 1993. Genetic subdivision of the pearl oyster Pinctada maxima (Jameson, 1901) (Mollusca: Pteridae) in northern Australia. Australian J. Mar. Freshwater Res. 44: 673.

Lester, L.J. 1983. Developing a selective breeding program for penaeid shrimp mariculture. Aquaculture. 33: 41--50.

Lavery, S. and J.B. Shaklee. 1989. Population genetics for two tropical sharks, Carcharhinus tilsoni and C. sorrah, in northern Australia. Australian J. Mar. Freshwater Res. 40: 451.

Miller, M.P. 1997. Tools for Population Genetic Analyses (TFPGA). Version 1.3, A Windows ه program for the analysis of allozyme and molecular population genetic data. Department of Biological Sciences-Box 5640. Northern Arizona University, Flagstaff. 30 pp.

Niwa, Y., A. Nakazawa, D. Margulies, V.P. Scholey, J.B. Wexler, and S. Chow. 2003. Genetic monitoring for spawning wcology of captivity yellowfin tuna (Thunnus albacares) using mitochondrial DNA. Aquaculture. 218: 387--395.

Ovenden, J. 2000.Development of restriction enzyme markers for red snapper (Lutjanus erythropterus and Lutjanus malabaricus) stock discrimination using genetic variation in mitochondria DNA. Molecular Fish- 
eries Laboratory, Southern Fisheries Centre. Produces for CSIRO Marine Laboratories as Part of the ACIAR Indonesia Snapper Project. $36 \mathrm{pp}$.

Palumbi, S.R. and C.S. Baker. 1994. Contrasting population structure from nuclear intron sequences and mtDNA of humpback whales. Mol. Biol. Evol. 11 : 426--435.

Raymond, M. and F. Rousset. 1995. GENEPOP (Version 1.2); Population genetic software for exact test and ecumenicism. J. Hered. 86: 248--249.

Rogers, J.S. 1972. Measures of genetic similarity and genetic distance. p. 145--153. In: Studies in genetics. VII. Ed., M.R. Wheeler. Univ. Texas Publ. 7213, 354 pp.

Sokal, R.R. and R.G.. Rohlf. 1981. Biometry. Freeman and Co. San Francisco. California. 776 pp.

Sugama, K., N. Taniguchi, and S. Umeda. 1988. An experimental study on genetic drift in hatchery population of red sea bream. Bull. Japan Sci. Soc. 54: 739--744.

Sugama, K. and A. Prijono.1998. Biochemical genetik differentiation among wild populations of Milkfish (Chanos-chanos) in
Indonesia. Indonesian Fish. Res. J. IV(1): 11 $-18$.

Sugama, K., Haryanti, and F. Cholik. 1996. Biochemical Genetics of Tiger Shrimp Penaeus monodon: Description Electrophoresis Detectable Loci. Indonesian Fish. Res. J. II(1): 19--28.

Taniguchi, N., H.S. Han, and S. Tsujimura. 1994. Variation in some quantitative traits of clones produced by chromosome manipulation in Ayu, Plecoglossus altiveliss. Aquaculture. 120: 53-60.

Wild, A. 1994. A review of the biology and fisheries for yellowfin tuna, Thunnus albacares, in the eastern Pacific Ocean. FAO Fish. Tech. Pap. 336: 52--107.

Wibowo, A.H. 2001. Analisis Variasi Gen dan Struktur Populasi Genetik Ikan Napoleon Wrasse (Cheillinus undulatus). Thesis. Program Pascasarjana Universitas Brawijaya Malang. 53 pp.

Yeatman, J. and J.A.H. Benzie. 1994. Genetic structure and distribution of Photololigo spp. In Australia. Marine Biology (Berlin). 118: $79--87$. 